\title{
Primary hypothyroidism mimicking a pituitary macroadenoma: regression after thyroid hormone replacement therapy
}

\author{
Gaurav Saigal
}

Received: 26 December 2008 / Accepted: 8 January 2009/Published online: 18 February 2009

(C) Springer-Verlag 2009

Sir,

This letter is in response to the paper "Primary hypothyroidism mimicking a pituitary macroadenoma: regression after thyroid hormone replacement therapy" by Dr. K. S. Eom et al. [1]. The authors state that the prominent soft tissue noted within the sella was felt to be a mass initially and later confirmed to be due to pituitary hyperplasia. I respectfully disagree. The only way to definitely diagnose a soft tissue prominence in the sella to be a mass is to demonstrate an area of differential enhancement. This is best achieved by doing a post-gadolinium dynamic imaging study of the sella. Other secondary findings of a mass would include asymmetric enlargement of the gland, deviation of the pituitary stalk to one side, or asymmetric contour of the superior convexity of the gland. None of these findings were seen or reported by the authors. The pituitary gland is definitely enlarged (as shown in the exquisite images). However, the homogenous enhancement and diffuse enlargement of the gland should make one more concerned for pituitary enlargement due to hyperplasia rather than the existence of a mass. The stated clinical findings should also lead one to suspect pituitary hyperplasia due to hypothyroidism as a cause of the imaging appearance.

\section{Reference}

1. Eom KS, See-Sung C, Kim JD et al (2009) Primary hypothyroidism mimicking a pituitary macroadenoma: regression after thyroid hormone replacement therapy. Pediatr Radiol 39:164-167

\section{G. Saigal $(\bowtie)$}

Department of Radiology,

University of Miami Miller School of Medicine,

P.O. Box 016960, Miami, FL 33101, USA

e-mail: saigalgaurav@yahoo.com 